\title{
Resolving Douglass C. North's 'puzzle' concerning China's household responsibility system
}

\author{
Simon Deakin and Gaofeng Meng* \\ Centre for Business Research, University of Cambridge, Cambridge, UK \\ ${ }^{*}$ Corresponding author. Email: gm669@cam.ac.uk
}

(Received 2 August 2020; revised 22 September 2021; accepted 22 September 2021; first published online 15 October 2021)

\begin{abstract}
This paper considers Douglass C. North's 'puzzle' concerning China's household responsibility system (HRS) and offers a possible solution. China's HRS, which has evolved over the past four decades to become its dominant form of rural land ownership, has stimulated spectacular economic growth and poverty reduction; however, it is based on a type of ownership which is far removed from the property rights regime which North regarded as essential. Two features of the HRS merit attention. The first is 'split ownership': this refers to the allocation of different aspects of ownership, including rights of access, use, management, exclusion and alienation, to a range of individual and collective actors with interests in the land in question. The second is polycentric governance: rules governing land use are derived in part from community-level action and in part from state intervention. We argue that in explaining the functioning of the HRS we need to move beyond the narrow conception of legally enforced private property rights on which North relied. We should instead embrace understandings of ownership as an emergent, diverse and complex institution, of the kind emphasized by A.M. Honorés legal theory of ownership and Elinor Ostrom's theories of the common-pool resource and polycentric governance.
\end{abstract}

Key words: China; common-pool resource; household responsibility system; ownership; polycentric governance; property rights

\section{Introduction}

According to Douglass C. North, 'well-developed property rights' are a means to increase productivity and 'market efficiency'; in their absence, we should expect to see weak economic performance leading to stagnation and decline (North, 2005b: 1-2). For North, following Demsetz (1967), property rules are well developed when they confer indivisible rights on individual owners. Thus, the institution of property works well when it is individual and private as opposed to communal and public. It follows that the state should not assume the role of owner of assets and resources beyond what is needed to ensure its own functioning, by ensuring, for example, that certain core governmental services are retained in public ownership. At the same time, the state has a critical role in supplying legal support for and protection of the property rights of individuals. As part of this role, the state needs to place limits on its own powers of expropriation: this implies a polity which respects democratic decision making and the rule of law (North, 1990; Prybyla, 1990).

This theorization, North accepted, did not very well explain China's rapid economic growth over the decades prior to the appearance of his major works in the 1990s and 2000s. China, he recognized, 'has none of the conditions that we think of as making for successful economic growth. It has no clearly specified property rights and it has a judicial system that is essentially arbitrary' (North, 2004: 5), a feature of its development which he described as 'puzzling' (North, 2005a). Its larger 
firms were state-owned while the local town-village enterprises 'hardly resembled the standard firm of economics'; its political structure, meanwhile, 'remains to this day a communist dictatorship' (North, 2005a). China's system of rural land ownership, known as the household responsibility system ('HRS'), had emerged out of community-level initiatives in the late 1970s before being taken up by county and provincial-level governments and eventually embedded in national legislation. Far from respecting the principle of indivisible property rights over land, the HRS divides ownership between collective structures and individual households. The 'bundle' of property rights which, according to what North called the 'standard models of economic and political theory' (North, 2005a) should be indivisibly vested in single owners, were distributed among a range of actors and entities. Under the HRS, the 'simple question: who owns the land?' could not be given a simple answer: different accounts described land under the HRS as having multiple owners (Ho, 2005: 2) or none at all (Zhu and Jiang, 1993: 447). Yet, this was a system under which there had been dramatic increases in agricultural output and equally dramatic improvements to the livelihoods of millions of Chinese farmers: rural net income grew at over $10 \%$ per annum in the decade from 1979 (Wong, 2014), a period during which decollectivization of agriculture responsible for major gains in total factor productivity and resulting output growth (Lin, 1992). According to a World Bank report published in 2021, the HRS reforms played a major role in a process in which hundreds of millions of people were lifted out of poverty, at the same time as significant improvements in access to health, education and other services were being achieved (World Bank, 2021).

In this paper, we take a closer look at the HRS. When we do this we see that it is less of a puzzle than it might seem, although to understand it requires a modification of what North called the 'standard' theory. Under the HRS, rural land in China is not 'ownerless'. Peasant households have rights to possess, use and manage the land they occupy, and to enjoy the resulting income, albeit on a time-limited basis and subject to certain restrictions; when time-limited rights expire, they revert to communal and collective entities which thereby retain a residuary interest in the land along with various control rights. The HRS signifies a move from collective ownership to a form of 'split' ownership which allows households to capture returns from the possession and occupation of the land while a role for communities in its governance. It is a hybrid structure which is neither entirely private, nor entirely public. By virtue of the HRS, rural land in China has acquired elements of what Ostrom (1990) refers to as a 'common-pool resource', meaning a resource which is not a pure public good and so is subject to depletion, but which is collectively managed through a combination of communal norms of an emergent and self-organizing kind, on the one hand, and formal law, on the other, of the kind associated with multi-level or 'polycentric governance' (Ostrom, 2005).

The HRS also exhibits the multi-dimensional features of ownership as a legal institution, as emphasized by Honoré (1961). Although the incidents of ownership can be unified, leading to 'a single human being owning, in the full liberal sense, a single material thing', this is only one possible model: just as plausible is the case in which 'the standard incidents are divided between two or more persons' (Honoré, 1961: 107) which can include juridical persons and collective entities of various kind as well as individual people. And just as the case of the HRS suggests that ownership is more diverse and multi-functional than the standard theory proposes, governance is not confined to a straightforward duality between communal action and state intervention. Communal norms may have emergent features, while also depending on the state for their stabilization and dissemination; formal law, as Honoré shows, is capable of expressing multiple versions of the ownership concept, and allowing bundles of rights to be divided and recombined in ways which reflect solutions to the problems posed by interdependent uses of resources.

This introduction is followed by four sections. Section 2 outlines what may be called the standard model of property rights and economic growth on which North, building on Demsetz, relies. Section 3 then considers the origin and characteristics of the HRS. Section 4 employs Honorés concept of ownership and Ostrom's theory of the common-pool resource to analyse the HRS and its mode of operation with respect to rural land. Section 5 provides a concluding assessment. 


\section{The 'standard' theory of property rights and economic development: Demsetz and North}

Demsetz (1967) draws a distinction between communal ownership, private ownership and state ownership. In principle, 'the bundle of property rights associated with a resource is divisible' (Alchian and Demsetz, 1973: 18). However, communal ownership, in which the bundle is divided up among the members of a group, can be expected to develop into private ownership over time because of the latter's implications for efficient cost internalization and the alignment of investments and returns:

private ownership of land will internalize many of the external costs associated with communal ownership, for now an owner, by virtue of his power to exclude others, can generally count on realizing the rewards associated with husbanding the game and increasing the fertility of his land. This concentration of benefits and costs on owners creates incentives to utilize resources more efficiently (Demsetz, 1967: 356).

Thus, the key aspect of private property is that it is individualized: 'If a single person owns land, he will attempt to maximize its present value by taking into account alternative future time streams of benefits and costs and selecting that one which he believes will maximize the present value of his privately-owned land rights' (Demsetz, 1967: 355). This is an echo of the juridical description of property, contained in Blackstone's Commentaries, as 'that sole and despotic dominion which one man claims and exercises over the external things of the world, in total exclusion of the right of any other individual in the universe' (Blackstone, (2016) [1766]). Along with exclusion comes the right of alienation: 'when a transaction is concluded in the marketplace, two bundles of property rights are exchanged' (Demsetz, 1967: 347). Demsetz's theory places private property and freedom of alienation at the core of capitalism, in contrast to public property and central planning, which he associates with socialism (Demsetz, 2002).

North foregrounded the role of property rights in promoting economic growth from an early stage in the development of his ideas. In The Rise of the Western World, written with Robert Paul Thomas, North was already arguing that 'efficient economic organization is the key to growth' and that 'efficient organization entails the establishment of institutional arrangements and property rights that create an incentive to channel individual economic effort into activities that bring the private rate of return close to the social rate of return' (North and Thomas, 1973: 1). Adapting Demsetz, North's early work with Robert Paul Thomas draws a distinction between developed and underdeveloped property rights. For North and Thomas, it is the evolution from the 'underdeveloped' common property of the Middle Ages to the liberal concept of full ownership that underpins the rise of the West. The feudal ownership of land was in essence a form of 'split ownership' in which 'several persons had jurisdiction or held and shared particular rights to the same piece of land' (North and Thomas, 1973: 63).

With the rise of the enclosure movement from the last Middle Ages onwards, the dominant conception of property rights became one which allowed the individual proprietor to exclude the wider community from access to land (North and Thomas, 1973: 151-153). Underpinning this development is the evolution of a state capable of defining 'the formal economic rules of the game' (North, 2005a: 57). In his work with Barry Weingast (North and Weingast, 1989), North specifically identifies the legal and political changes following the Glorious Revolution of 1688, which he sees as securing private property rights against state expropriation, as the foundation for the British Industrial Revolution and, more generally, for the rise of capitalism in the West.

Developing this theme, In Institutions, Institutional Change, and Economic Performance North argues for institutions with the feature of 'adaptive efficiency'. Whether an economy is moving in an adaptively efficient direction turns on how far its institutions provide 'incentives to encourage the development of decentralized decision-making processes that will allow societies to maximize the efforts required to explore alternative ways of resolving problems' (North, 1990: 81). Although North accepts that England's distinctive historical trajectory cannot be fully replicated elsewhere, he 
believed that it reflects a tendency of economies across the West which is mirrored in the evolution of other countries including the USA and France (North et al., 2009). The implication of this approach is that the legal-institutional model of Western economies represents the 'end-point' of economic development (Faundez, 2016: 373).

North's thought evolved over time, towards an explicit recognition that institutional change takes place in the context of a 'non-ergodic' world (North, 1999, 2005b). This implies an openness and indeterminacy to the process of institutional change which is at odds with the emphasis in Demsetz (1967) on the spontaneous emergence of efficient property rules in response to underlying economic conditions. At the same time, North does not appear to have at any point rejected Demsetz's emphasis on the indivisibility of ownership under efficient property rights regimes, and he was ready to recognize the challenge to his own theories posed by China's rise. On the one hand, 'there have been a few spectacular successes' outside European and North America, 'more particularly China', which has avoided 'slavishly imitating Western institutions' (North, 2005b: 159). Thus, 'starting with the Household Responsibility System, the Chinese developed an incentive structure which managed to produce rapid economic development without any of the standard recipes of the West' (North, 2005b: 159). On the other hand, North thought that Chinese institutions could be expected to converge with those of the West over the course of time: 'down the road the Chinese must embed the incentive system in the political/economic structure is they are to continue their rapid development and that will probably require institutions that come much closer to having the adaptive efficient features of western societies' (ibid.). A closer look at the HRS can help us assess this claim.

\section{The genesis and evolution of the HRS}

\subsection{Community level origins}

There were three major changes to property rights in rural arable land under the leadership of the Chinese Communist Party (CCP) in the course of the 20th century. The first was the shift from feudal landlord-based ownership to peasant-held private property from the early 1920s to the early 1950s under the slogan 'land to the tiller', a programme initiated by the Nationalist Party under Sun Zhongshan and completed by the CCP. The second was the abolition of peasant-held private property and the establishment of collective property advocated by Mao Zedong. The consequence was the Commune System of 1956-1978 and the associated establishment of full collective ownership. The third change, in 1979, was decollectivization and the establishment of the HRS under the leadership of Deng Xiaoping. The essence of the HRS is that it returned a series of use rights to peasant households but preserved the communal possession of land and redistributive rights in the hands of the collective (Lin, 1990; Meng, 2019).

The HRS first emerged as a community-level institutional arrangement. In December 1978, 20 peasants, including two cadres of the Xiaogang production team in Liyuan Commune in Fengyang County of Anhui Province, one of the poorest communes in a predominantly rural province, signed a secret agreement to make their own rules of production and distribution in order to increase agricultural productivity and solve the problem of food and clothing shortages. It is relevant to quote the agreement here:

We allocate land to each individual household. Every head of the household signs their name and seals with their fingerprint on the agreement. If we succeed, each household ensures that the whole year's state procurement is fulfilled and will not ask for money and grain from the government. If it fails, we cadres are willing to be put into prison or killed; other members of the production team will collectively raise our children until they are eighteen years of age (GB54563, 1983, our translation).

The authenticity of this document has been questioned, but although the original version may have been lost, it is thought that the details are accurate (Ling, 1997; Wang, 1988). 
The official position at this point was that collective production teams were the basic unit of production and accounting; for the commune to contract for the supply of labour from individual households was prohibited because it was considered to be against the socialist principle of collective farming, although contracting for the supply of labour from groups was permitted. Household-based production was regarded as capitalist, with team-based production privileged as socialist, according to Mao's thinking. Documents issued at the Third Plenum of the 11th Central Committee were explicit: 'No fixing the farm output quotas for each household, no dividing land and labouring individually' (quoted in $\mathrm{Wu}, 2016$ ). The view of the Anhui provincial government as set out in the 'Six Articles' specified 'not permitting the contracting of production to individual households and not permitting the figuring of compensation according to output' (Wang et al., 1989: 385).

Nonetheless, communes in Fengyang County were experimenting by contracting production to groups from the late 1970s. To begin with, most production teams made choices within the existing set of constraints. Initially, then, the peasants of Liyuan Commune were still following the official position. In total, 195 people across 20 households in the entire brigade were split into four task groups, but this was not successful; later, they were split into eight groups, but were still unsuccessful. It was then that officials began discreetly to contract production to households, on the basis that this was necessary to motivate them $(\mathrm{Wu}, 1979)$.

\subsection{Support from local officials}

Thus, the very first attempts at what became the HRS, in Xiaogang village, were the result of trial and error; communities learned how to rationalize production relations across households, individuals and the collective. The rules created by communities were, nonetheless, later converted into formal property rights regimes. The role of central government was to legitimatize and institutionalize an original institutional choice which emerged from the ground up (Lin, 1987).

The Xiaogang villagers' experiment obtained the blessing of various local governments in Anhui Province from an early stage. Chen Tingyuan, the then first secretary of the CCP in Fengyang County, protected the Xiaogang villagers, and reported their initiatives to his immediate superior, Wang Yuzhao, the first secretary of the CCP in Chuxian prefecture. Wang, a support of rural reform, allowed Xiaogang village to continue with the experiment for 3 years. At a provincial agricultural conference, Chen passed a report by the cadre Wu Tingmei to Wan Li, the first secretary of Anhui province (Wang et al., 1989), who expressed interest in the experiment. On 24 January 1980 Wan and other cadres visited Xiaogang. Wan is reported to have said:

The prefecture-level government allows you to contract with households for three years; I allow you five years. Only you can contribute more to the state, more to the collective, and your lives can improve.... It cannot be called the reversing of communism into capitalist restoration (Wang et al., 1989: 59).

Following Wan's public encouragement of the Xiaogang initiative, there was take-up in other parts of Anhui, enabling what had hitherto been a small-scale experiment to move to the provincial level. The role of provincial governments and their leaderships in the process of economic reform and change in the countryside at this time has been more widely noted (Chung, 1993, 2000).

Anhui Province may not have been the only context in which the experiments which became the HRS were being tried out. There is evidence of a village in Guizhou Province having adopted similar practices in secret, more than 10 years before the Anhui reforms were publicized. In this case, the villagers did not admit what they had been doing until the new policy was announced at the national level in $1980(\mathrm{Du}, 1985)$. If Anhui was not unique in experiencing local-level experimentation, it was nevertheless no accident that the reform was first taken up there at the level of provincial government, with key individuals in the leadership, including Wang Yuzhao and Wan Li, ready to act when the opportunity arose. 
Before Wan Li arrived in Anhui in the spring of 1977, Wang Yuzhao had organized 394 cadres to inspect 401 communes and brigades in order to re-evaluate the rural policy of 'Learning from Dazhai', the model of the commune system under Mao (Wang et al., 1989). By October $1977 \mathrm{Wan} \mathrm{Li,} \mathrm{having}$ considered the results of Wang's investigation, was already drawing up new provincial regulations for the organization of the agricultural sector $(\mathrm{Wu}, 2016)$. These stressed that the autonomy of the production teams should be respected, production beyond their immediate needs encouraged and private plots restored. It was clear that these policies were an implied criticism of the Dazhai model, and it has been suggested that they were intended to undermine Hua Guofeng, Mao's successor (Fewsmith, 1994). In February 1978, possibly with the backing of Deng Xiaoping, the details of Anhui's new provincial regulations were reported by the national People's Daily (Wang et al., 1989). The same year, a severe drought hit Anhui; this provided Wan Li with a further opportunity to push forward a reform programme, the thinking being that peasants would be given access to fallow land in order better to enable them to survive drought conditions (Wang et al., 1989).

\subsection{National-level institutionalization}

There is evidence that Deng Xiaoping was behind the decision to send Wan $\mathrm{Li}$, a known supporter of rural reform, to oversee agricultural policy in Anhui, as he had sent Zhao Ziyang to Sichuan with a similar mission (Bai and Kung, 2014). The early 1980s were a period when it became possible to question the assumptions underlying the Dazhai model. It was at this time that Deng said of his rivals: 'they are not clear about what capitalism is and what socialism is' (Deng, 1993: 227). In a speech discussing Marxist theory at a Central Committee plenum on 30 June 1984, he posed the question:

What is socialism and what is Marxism? We were not quite clear about this in the past. Marxism attaches utmost importance to developing the productive forces (Deng, 1984).

This was understood as contrasting sharply with Mao's position, which had equated decollectivization with a transition to capitalism. Reform was seen as needed because the Commune System had become associated with long-term economic stagnation and decline, and even starvation (Ashton et al., 1984; Li and Yang, 2005; Meng et al., 2015; Yixin, 2010). Thus, 'on the eve of reform in 1978, the whole country had a rural population of 250 million in half starvation mode' (Wu, 2016: xxvii). At that time, $80 \%$ of the Chinese population lived in the countryside. Deng linked rural development and improvement the fate of the wider economy: 'if the peasants did not shake off poverty, China would remain poor' (Deng, 1993: 237).

In March 1980, Wan reported on the rural reform efforts in Anhui province to Deng (Wu, 2016). This prompted a key discussion regarding the future of household-based production. At a meeting of the National People's Congress Standing Committee in April 1980, Zhao Ziyang and Wan Li were named as vice premiers of the State Council, and Wan replaced his rival, Wang Renzhong, as head of the State Agricultural Commission, a move which enabled him to initiate further reforms (Fewsmith, 1994).

In May 1980, after obtaining further reports on the economic viability and political acceptability of the Anhui model, Deng expressed his support for the HRS to two of his most prominent opponents, Deng Liquan and Hu Qiaomu. Not only did Deng openly approve the creativity of peasants in Anhui's Feixi and Fengyang counties; he also reassured the public that there were no concerns regarding the HRS: 'generally speaking, the main obstacle in dealing with current problems in the countryside is an insufficient amount of ideological freedom' (Deng, 1984: 275), a reference to Mao's view of householdbased production. Deng's speech was circulated among the central leaders, an important step in the evolution of the HRS from local experiment to national policy (Heilmann, 2008).

The HRS has since been credited with playing a major role in China's spectacular economic growth and related dramatic reduction in rural poverty (Bramall, 2009; Nolan, 1993; Upham, 2009), with contribution to output growth extensively mapped (Lin, 1989; McMillan et al., 1989; Wen, 1988). 
According to Lin (1992: 34), decollectivization 'is found to improve total factor productivity and to account for about half of the output growth during 1978-1984' (Lin, 1992: 34). Between 1979 and 1984, rural net income per capita grew by $11 \%$ annually (Wong, 2014), while 'the mean growth rate of per capita net income in China's rural areas was 6.69\% per year between 1980 and 2000' (Sun, 2012: 337). The HRS is also credited with a long- term, dynamic impact on the growth of agricultural productivity: 'the HRS had a significant positive effect on grain output and food supply in China, while also helping to reduce regional inequality' (Gibson, 2020: 14; on regional inequality see also Li and Gibson, 2013; Liu, 2013). Despite soaring income gaps (Whyte, 2010, 2014), the scale of China's reduction of extreme poverty is arguably unprecedented in human history (Ang, 2016; Chen and Ravallion, 2020; Ravallion, 2021).

This is not to say that the HRS has been free of critiques. It has been suggested, for example, that by perpetuating small-scale production it has deterred necessary investments at scale and over the longer term (Zhang and Donaldson, 2013; Zhu and Jiang, 1993). A further criticism, made by North himself (2005a), is that since China remains a 'dictatorship', there can be no guarantee that such property rights as are recognized in law and practice, including those associated with the HRS, will be preserved against arbitrary governmental action. These criticisms notwithstanding, it would seem that the HRS has not just endured but evolved over time in ways which suggest that it is both an 'efficient' mode of governance in the Northian sense of aligning private and social returns (North and Thomas, 1973: 1), and broadly 'adaptive' in its capacity to retain and diffuse the lessons of decentralized decision-making processes (North, 1990: 81).

\section{Analysing the HRS through the lens of Honoré and Ostrom's theories of property}

To explore in more detail the reasons for the enduring and adaptive nature of the HRS, this section takes a closer look at the incentive structures and modes of governance with which it is associated. We firstly argue that it contains features consistent with A. M. Honoré's conceptual model of legal ownership. We then consider the HRS as an instance of what Elinor Ostrom terms a common-pool resource. Where Honoré points to the complexity of legal understandings of property, Ostrom supplies an analytical understanding of the incentive properties of split ownership, in both cases highlighting the limitations of the 'standard' Demsetz-North model of property rights as an explanatory device, and throwing new light on the reasons for the success of the HRS.

\subsection{The HRS as unbundled ownership}

\subsubsection{Full ownership and split ownership in Honoré's model}

In his classic essay, Honoré (1961: 108) claims that 'certain important legal incidents' inherent in the idea of ownership are common to all legal systems. He suggests that 'the standard incidents of ownership do not vary from system to system in the erratic, unpredictable way implied by some writers but, on the contrary, have a tendency to remain constant from place to place and age to age' (1961: 109). He lists 11 'leading' incidents in 'mature legal systems': 'ownership comprises the right to possess, the right to use, the right to manage, the right to the income of the thing, the right to the capital, the right to security, the rights or incidents of transmissibility and absence of term, the prohibition of harmful use, liability to execution, and the incident of residuarity' (1961: 113).

When these standard incidents are concentrated in one person, there is the 'liberal concept of full ownership' recognized by Blackstone (2016 [1766]). The gist of Honoré's argument is that this model is not the only 'legally or socially important' way to organize ownership (1961: 113).

When the standard incidents are shared across two or more persons (Honoré, 1961: 107) they become various types of split ownership. Some of these 'persons' might be individual human beings, some of them collective or corporate bodies recognized by law, 'juristic persons' in Honoré's terms (1961: 142). Compared with 'the standard case of full ownership' (Honoré, 1961: 107), the various types of split ownership are complex. They include 'cases where the standard incidents are so divided, 
as to raise a doubt which of two or more persons interested should be called owner' (Honoré, 1961: 124). They may give the impression that either everyone or no-one is the owner. As such, they will 'present baffling problems to one who is compelled to fix on one interested person as the owner of the thing' (1961: 111).

Honoré also cautions against any assumption that 'full' ownership is a 'natural' or default condition. On the contrary, "historically speaking, the metaphor of "splitting" may mislead, for in some cases full ownership has been built up from the fragments, not vice versa' (Honoré, 1961: 142). Thus, in the history of English land law, the 'the standard incidents' were 'so divided between lord and tenant that the position of neither presented a sufficient analogy with the paradigm case of owning a thing' (Honoré, 1961: 109); while such a foundational concept as 'the alienable, heritable, and indefeasible fee simple' was a legal form which 'evolved from the inalienable and intransmissible tenancy in fee, subject to onerous incidents of tenure' (Honoré, 1961: 142).

\subsubsection{The property rights structure of the HRS}

A key feature of the HRS is that ownership is 'unbundled' in a dual sense. It is not just that property rights are shared between households and the collective; in addition, distinct features of ownership are identified and allocated to different individuals, entities and groups. Rights of possession, use and management are held by peasant households, but on a time-limited basis and subject to state-imposed restrictions dictating that rural land must be used for agricultural purposes. Initially, these use-rights were allocated for a period of 5 years; this period was extended to 15 years in 1984 and to 30 years in 1993 (Cheng and Tang, 1996). The 30-year term is now confirmed in the Land Administration Law (1999), the Rural Contract Law (2003) and the Property Law (2007). When households' leases terminate, the rights revert once more to the collective, which can re-allocate them, either to the previous tenant or to other members of the village. These are therefore what Honoré calls 'determinate rights'. The allocation to households of the right to manage - the right to 'decide how and by whom the thing owned shall be used' - has been particularly significant, for it has enabled peasants to make their own decisions about production and land use management, and to adjust their crop patterns in response to soil, temperature, rainfall and other region-specific differences (Lardy, 1983).

The HRS also gives households what Honore calls income rights, a concept which encompasses the 'fruits, rents, profits' and other benefits derived from the right to use. Under Maoist collectivization, the basic production and accounting unit belonged to the production team, and distribution was not directly linked to work performance. By contrast, under the HRS, households are allocated the right to receive a share of the income they generate from production. Initially, incomes were split with the collective, with households returning a specified percentage of their output back to the collective but retaining any output (or the proceeds from it) exceeding this quota. In 1994, however, the quota requirement was abolished and the right to income vested entirely in individual producers, who then became entitled to any benefits (including income, rents and profits) derived from the use-rights they possessed, once they had met their obligations to the state and the collective in the form of agricultural taxes and village-based community charges (Oi, 1999). Some see this as one of the springboards of Chinese rural economic growth. It has certainly 'greatly benefited rural families' (Joel, 2012): where they decide to sublet, households can use rents from land to protect against loss of other sources of income, a form of subsidy which to some degree mitigates the precarity of employment and wages affecting migrant workers (Zhang and Donaldson, 2013).

Households have also acquired 'transmissibility' rights, the ability to bequeath their interests to successors. What this means is that the time-limited rights of use, possession, management and income held by peasants can be inherited by their successors, although only for the duration of the contract period. Peasants have also begun gradually to acquire rights to transfer their use-rights. In 1988 constitutional revisions confirmed that land use-rights could be 'transferred according to law', and Article 128 of the Property Law (2007) formally permits subcontracting, although this power remains subject to important constraints: under the rules of the Rural Contracting Law (2003) the transfer must be 'a voluntary, consultative and paid lease', the land must still be used for agricultural purposes, and the 
terms of lease must not exceed 30 years. As the periods over which use rights are granted to households have lengthened, these rights of transmission have become increasingly important and valuable.

Under the HRS, then, within a framework in which certain key land ownership rights remain vested in collectives, many of the rights associated with ownership - the right to use, to possess, to manage, to access income and so on - have been allocated to individual households for specified time periods and subject to various restrictions. However, when the various time-limited rights awarded to households terminate, they revert to the collective, which retains what Honore calls a 'residuary right in the things owned' (1961: 128). This is significant not least because many see the possessors of these residual rights as the 'owners', hence the continuing depiction in China of collectives as 'landowners'. In Honoré's terms, however, the HRS is an example of 'split ownership': the 'ultimate residuary right is not coupled with present alienability or with the other standard incidents' (Honoré, 1961: 128).

It is this feature in particular that renders the location of ownership in the case of the HRS a 'puzzle' to economists and political scientists basing their analysis on the standard model. Whenever he went to 'a village, a rural enterprise, or a mosque', Peter Ho tells us, he began by asking 'a simple question: Who owns the land?' But, he didn't get simple answers: 'the same plot of land' was, apparently, 'owned by as many different persons and legal entities as the question was put to' (Ho, 2005: 2). Seeking an answer to the same question, Zhu and Jiang (1993: 447) drew the conclusion that under the HRS 'no one in the community is a real owner of land'.

For these writers, the property rights structure of the HRS was assumed to be 'ambiguous'. However, as Qiao and Upham (2015) suggest, asking 'who owns China's land' is unhelpful and, in a sense, misleading. The unbundling of ownership into its constituent parts is not a contingent feature of the HRS, but at its core. It is by separating and dividing the rights in the ownership bundle and allocating key ownership rights to individual farming households but with restrictions that the HRS has provided individual farmers with incentives to increase productivity within a broad framework of collective land ownership (Kung, 2000). In 2007, after a lengthy and heated 13-year debate, the Chinese state endorsed the HRS in its first comprehensive Property Law, resisting intense pressure, both from within and without, to privatize rural land and adopt a system of full liberal land ownership (Wong, 2014).

\subsection{Rural land under the HRS as a common-pool resource}

\subsubsection{Property without alienability}

Rural land under the HRS has features which Ostrom identifies as a 'common-pool resource' which is a fourth type of good, additional to the pure private goods and public goods defined by Samuelson (1954) and Buchanan's club goods (Buchanan, 1965). A common-pool resource 'shares the attribute of subtractability with private goods and difficulty of exclusion with public goods' (Ostrom, 2010: 644645). Ostrom develops a typology of unbundling which is based on empirical observation of the management of common land interests in fisheries, forests and irrigation systems. Schlager and Ostrom (1992), building in part on Commons' earlier analysis (1968 [1924]), identify five property rights that individuals using a common-pool resource might enjoy: (i) access, (ii) withdrawal, (iii) management, (iv) exclusion and (v) alienation (see also Ostrom, 2010: 651). The precise combination of these rights differs from one context to another, but a general feature of common-pool resources is that the right of alienation is not unqualified, or may not even be present.

The idea that there can be property in land without there being a full right of alienation is a central feature of the HRS. Households do not have the right to the capital in land - 'the power to alienate the thing and the liberty to consume, waste, or destroy the whole or part of it' (Kung, 2000). In China not only is there an obligation to use land 'rationally' (which would seem to exclude the liberty to destroy); the right to sell and alienate is unambiguously in the hands of collective bodies (here, government units beyond the township level: Hodgson and Huang, 2013). Under Article 10 of the 2004 Constitution, 'no organization or individual may appropriate, buy, sell, or otherwise engage in the transfer of land by unlawful means', and according to the National People's Congress Legal Affairs 
Work Committee, the right to the proceeds from the sale of land 'belongs to the central people's government and...the State Council may decide the distribution of profits from state-owned land' (RFGW, 1990).

The household's right to security of property - the right to be 'able to look forward to remaining owner indefinitely' - is qualified, but this in this respect the HRS is not unlike many other property regimes. The Chinese state can expropriate land in order to construct roads, railways and other public infrastructure, as long as it follows certain procedures and provides 'reasonable compensation' and 'appropriate resettlement' (Wong, 2014: 21). The state can also convert rural land into urban land. But, as Honoré recognizes (1961: 120), in principle 'a general right to security, availing against others, is perfectly consistent with the existence of a power to expropriate or divest in the state or public authorities'. In this sense, 'ownership has never been absolute'; it has always had 'a social aspect', usually 'expressed in...the prohibition of harmful use, liability to execution for debt, to taxation, and to expropriation by the public authority' (Honoré, 1961: 145-146). As Ostrom notes, many scholars she cites Alchian and Demsetz (1973), Anderson and Hill (1990) and Posner (1975) - have 'presumed that unless users possessed alienation rights - the right to sell their property - they did not have any property rights' (Ostrom, 2010: 250). However, this is to take just one 'incident' of ownership as synonymous with the whole.

\subsubsection{Polycentric governance}

A second feature of Ostrom's studies of common-pool resources relevant to the HRS is that it helps to explain its distinctive combination of governance from below, with the essential structure of the system emerging from community level organization, with support from government and national-level institutionalization through the formal legal system.

Thus, the HRS is both a community-inspired institutional arrangement that operates at a village level to generate productive and innovative results at its origin, and also a governmental institutional arrangement that operates at the national level. The emergence of the HRS from the agreements made by the 20 Xiaogang villagers is an example of a community self-consciously changing the rules of land use in a collective choice setting. It was neither the result of a competitive rule making process, mimicking market exchange, nor imposed by state bodies, even if the model was later adopted by and extended through legislation. It is characteristic of processes of rule formation which Ostrom characterizes as "rich mixtures of "private-like" and "public-like" institutions, defying classification into a sterile dichotomy' (1990: 14). She relatedly suggests that 'neither the state nor the market is uniformly successful in enabling individuals to sustain long-term, productive use of natural resource systems'. Institutional change associated with common ownership and management of land does not have to 'come from outside and be imposed on the individual affected' (ibid.).

Although Ostrom mapped the reality of self-governance in her empirical studies, she was cautious about generalizing from the instances she observed. On the one hand, 'communal ownership, rather than private ownership or central control, can be an optimal institutional arrangement for some types of common-resource problems' (Ostrom, 1987: 251-252). Thus, famously, she showed that the 'tragedy of the commons' was avoidable (Ostrom, 1987, 1990, 1993; Ostrom et al., 1994). On the other hand, she insists that there is no one-size-fits-all solution, and that no single model, whether it is user self-governance, the state, or privatization, can resolve all problems related to commons management issues in all contexts (Ostrom, 2007, 2009a, 2010). She also recognizes potential limits to the common-pool resource as a mode of governance, particularly when it operates at scale:

There are many well-documented examples of private property, community property, and government property systems that work effectively over time to keep the common-pool resource sustainable. Unfortunately, there are also a multitude of empirical examples where private, community, or government ownership is faltering or has collapsed. There are other examples where resource users have not succeeded in overcoming common-pool dilemmas - usually when the resource system is very large (Ostrom, 2009b: 751). 
The HRS solves one set of problems, arising from the absence of property rights under the Commune System, leading to free-riding and under-production (Ireland and Meng, 2017; Meng, 2019). However, the HRS is not free of difficulties. A central part of Ostrom's thought is the role played in the emergence of sustainable governance solutions of meta-level conditions which she refers to as 'design principles'. For Ostrom, a design principle is 'an essential element or condition' that helps to account for the success of common-pool resource institutions 'in gaining the compliance of generation after generation of appropriators to the rules in use' (Ostrom, 1990: 90). Among these conditions is preservation of an equilibrium between centralized rule-making through the state and local autonomy: 'if external governmental officials presume that only they have the authority to set the rules, then it will be very difficult for local appropriators to sustain a rule-governed [common-pool resource] over the long run' (Ostrom, 1990: 101). At the same time, Ostrom does not reject a role for the state: 'if a political regime does not provide arenas in which low-cost, enforceable agreements can be reached, it is very difficult to meet the potentially high costs of self-organization' (Ostrom, 1990: 146). She also accepts that some minimum degree of recognition from the state authorities can be essential to strengthen the capacity of users' rights to self-organize effectively over time (Ostrom, 2005).

Whether it is truly possible to translate the lessons of self-organization into larger scale arrangements remains, for some, an open question. David Harvey, for example, discusses Ostrom's empirical findings in the following terms:

most of her examples involved as few as a hundred or so appropriators. Anything much larger (her largest example was 15,000 people), she found, required a 'nested' structure of decisionmaking, because direct negotiation between all individuals was impossible. This implies that nested, and therefore in some sense 'hierarchical' forms of organization are needed to address large-scale problems such as global warming (Harvey, 2012: 68).

Similarly, Mark Pennington (2013) argues that while Ostrom provides an analytical framework to explain the success of small-scale institutional arrangements, she lacks a robust account of when, if ever, top-down government interventions are to be preferred.

These criticisms may be missing the point of Ostrom's analysis, which is that polycentric governance is not simply about decentralization. At first sight, the institutional change which occurred when the Commune System gave way to the HRS was a move from a highly centralized and hierarchical structure imposed by the state to a system embedding the lessons of self-organization and experimentation by local actors. However, the contrast here is too strong. The HRS was initiated from below by the peasants in many areas but it had to be 'nested' in larger local, provincial, structures in order to endure. The rights of households at the village level to make their own rules had to be recognized by the upper tiers of government, beginning with the counties and provinces, and extending upwards to the national leadership, governmental institutions and state constitution. As Ostrom recognized, 'a common-pool resource is closely connected to a larger social-ecological system', so that its governance is not straightforwardly localized, but is 'organized in multiple nested layers'.

\section{Conclusion}

Douglass C. North placed the institution of private property at the core of a theory of economic development. Since his theory seeks an explanation of the origins of capitalism and the related rise of the West, it faces a difficulty in the more recent rise of China, a difficulty which North acknowledged. China's system of land ownership, the HRS, fails to conform to the 'standard' model of property rights which North, adapting Harold Demsetz, associated with individualized and indivisible ownership. The HRS is a system of hybrid or split ownership in which rural households have time-limited rights of possession, use and management of land, while collective entities retain a number of residuary rights including control over the manner of land use and powers to restrain its alienation. This model is widely credited ending a period of economic stagnation associated with the collective ownership 
and control of land which preceded it. Although claims about the role of the HRS, as with any complex institution, may be contested, what is not in doubt is that it has endured throughout the period of China's rapid economic growth since the late 1970s to the point of being recognized in formal legal reforms and embedded at the highest level of state policy. From a Northian perspective on the developmental role of institutions, this is a 'puzzle' in need of resolution.

We have suggested in this paper that the 'puzzle' of the HRS can best be understood as a case study in institutional evolution. According to North, it is the adaptiveness of institutions which is ultimately responsible for their efficiency and hence for their contribution to economic development and growth. The 'liberal' or 'standard' model of indivisible ownership, which unites the different aspects of property in the hands of a single person, provides one kind of solution to the problem of efficient resource use, by aligning long-term costs and benefits of arising from investments in land. However, this model is not the only solution which can be observed at the level of practice or in systems of formal law, and nor is its appearance to be understood as the inevitable culmination of an evolutionary process in which less efficient alternatives were discarded.

As A. M. Honoré has shown, the legal concept of property is complex and layered, to the point where it is normal to find multiple claims operating on a single resource or asset. The 'unbundling' of property which Honoré identifies as a core feature of legal thought in the West finds a parallel in the empirical studies of communal land use systems conducted by Elinor Ostrom and her collaborators. Her concept of the common-pool resource explains the existence of a fourth category of goods, beyond private, public and club goods, which are subject to norms of collective management and control beyond the binaries of market and state, private and public. Her account directs attention not just to the distinctive incentive structures operating in hybrid land use regimes, but to the processes by which they emerge and are stabilized. Polycentric governance, combining self-organization and learning at the community level with the recognition and diffusion of local practices through formal legal and governmental institutions, may be both a good fit for understanding institutional change, and a better basis for institutional design than the alternatives of unmediated market-based exchange, on the one hand, and top-down state control, on the other.

Thus, the key to the HRS is that it is both a community-level institution, and a governmental one. It owes it origins to self-organizing initiatives among peasant households, but its stabilization and diffusion would not have been possible if it had not been taken up by governmental officials and eventually formalized in legislative and constitutional texts.

In pointing to the distinctive incentive properties of the HRS and the history of its emergence, stabilization and wider diffusion, we appreciate that there are a number of issues that remain to be resolved concerning its mode of operation and prospects for further development. Although it is possible to point to complementarities between informal and formal modes of governance in the context of the HRS, research remains to be done on understanding the role of formality in general (Stinchcombe, 2001), and formal law in particular (Deakin et al., 2017), within economic governance. Research in this area may be expected to throw light on the continuing debate over how states of different kinds (liberal or non-liberal as the case may be) can credibly commit to the protection of property rights.

The arguments we have presented here also have implications for how we should understand North's contribution to the theory of property rights. Although never expressly rejecting Demsetz's emphasis on indivisibility and individuality of ownership, he also acknowledged Ostrom as a 'pioneer' who had 'probably done more than anybody else in her work examining common pool problems and ways [to show how] we can effective structure problems using common property' (North, 1999: 10). Integrating the insights of North and Ostrom into a theory of property rights which is capable of explaining the huge diversity of such rights that can be observed in practice, and their complex relationship to development, is an ongoing project (Faundez, 2016; Ireland and Meng, 2017; Upham, 2009).

These are issues for future research. In this paper, we have used the case of the HRS to show not just that institutions matter to development, but that institutions can take many forms. In highlighting 
the complexity of property as both legal concept and social practice, our analysis reminds policy makers that privatization and decentralization are not the only options when it comes to land reform. On the contrary, it is possible to observe, and to devise, property rights regimes that reconcile in various ways the incentive properties of private ownership with a collective framework for the management and use of land and other resources.

Acknowledgements. We are very grateful to the journal's three referees and to the editor for their feedback. We would also like to thank Anthony Crow, David McLellan, David Smith, Richard Stanley and Pauline Walters for their helpful comments.

\section{References}

Alchian, A. and H. Demsetz (1973), 'The Property Rights Paradigm', Journal of Economic History, 33(1): 16-27.

Anderson, T. L. and P. J. Hill (1990), 'The Race for Property Rights', Journal of Law and Economics, 33(1): $177-197$.

Ang, Y. (2016), How China Escaped the Poverty Trap, Ithaca: Cornell University Press.

Ashton, B., K. Hill, A. Piazza and R. Zeitz (1984), 'Famine in China, 1958-61', Population and Development Review, 10(4): 613-645.

Bai, Y. and J. K. S. Kung (2014), 'The Shaping of an Institutional Choice: Weather shocks, the Great Leap Famine, and Agricultural Decollectivization in China', Explorations in Economic History, 54(C): 1-26.

Blackstone, W. (2016) [1766], Commentaries on the Laws of England (Vol. 2), Oxford: Oxford University Press.

Bramall, C. (2009), Chinese Economic Development, London: Routledge.

Buchanan, J. M. (1965), 'An Economic Theory of Clubs', Economica, 32(125): 1-14.

Chen, S. and M. Ravallion (2020), 'Reconciling the Conflicting Narratives on Poverty in China', NBER Working Paper 28147.

Cheng, Y. and S. Tang (1996), 'Agricultural Land Reform in a Mixed System: The Chinese Experience of 1984-1994', China Information, 10(3/4): 44-74.

Chung, J. H. (1993), The Politics of Policy Implementation in Post-Mao China: Central Control and Provincial Autonomy under Decentralization, University of Michigan, unpublished dissertation.

Chung, J. H. (2000), Central Control and Local Discretion in China: Leadership and Implementation During Post-Mao De-Collectivization, Oxford, England: Oxford University Press.

Commons, J. R. (1968) [1924], Legal Foundations of Capitalism, New York: Macmillan.

Deakin, S., D. Gindis, G. M. Hodgson, K. Huang and K. Pistor (2017), 'Legal Institutionalism: Capitalism and the Constitutive Role of Law', Journal of Comparative Economics, 45(1): 188-200.

Demsetz, H. (1967), 'Toward a Theory of Property Rights', American Economic Review, 57(2): 347-359.

Demsetz, H. (2002), 'Toward a Theory of Property Rights II: The Competition Between Private and Collective Ownership', Journal of Legal Studies, 31(S2): S653-S672.

Deng, X. (1984), 'Guanyu Nongcun Zhengce Wenti' ['On Questions of Rural Policy'] in Deng Xiaoping Wenxuan [Selected Works of Deng Xiaoping], Beijing: People's Publishing House.

Deng, X. (1993), Selected Works of Deng Xiaoping (Vol. III), Beijing: People's Publishing House.

Du, R. (1985), China's Rural Economic Reform, Beijing: Social Science Press.

Faundez, J. (2016), 'Douglass North's Theory of Institutions: Lessons for Law and Development', Hague Journal on the Rule of Law, 8(2): 373-419.

Fewsmith, J. (1994), Dilemmas of Reform in China: Political Conflict and Economic Debate, Armonk, New York: M. E. Sharpe. GB54563 (1983), 'Household Responsibility System: In the National Museum of Chinese History'. Available at http://www. china.org.cn/features/60years/200909/16/content_18534697.htm.

Gibson, J. (2020), 'Aggregate and Distributional Impacts of China's Household Responsibility System', Australian Journal of Agricultural and Resource, 64(1): 14-29.

Harvey, D. (2012), Rebel Cities: From the Right to the City to the Urban Revolution, London: Verso.

Heilmann, S. (2008), 'From Local Experiments to National Policy: The Origins of China's Distinctive Policy Process', China Journal, 59: 1-30.

Ho, P. (2005), Institutions in Transition: Land Ownership, Property Rights and Social Conflict in China, Oxford: Oxford University Press.

Hodgson, G. M. and K. Huang (2013), 'Brakes on Chinese Development: Institutional Causes of a Growth Slowdown', Journal of Economic Issues, 47(3): 599-622.

Honoré, A. M. (1961), 'Ownership', in A. G. Guest (ed.), Oxford Essays in Jurisprudence, Oxford: Oxford University Press, pp. 107-147.

Ireland, P. and G. Meng (2017), 'Post-Capitalist Property', Economy and Society, 46(3-4): 369-397.

Joel, A. (2012), 'Sino-seismology', New Left Review, 76: 128-135.

Kung, J. K.-S. (2000), 'Common Property Rights and Land Reallocations in Rural China: Evidence from a Village Survey', World Development, 28(4): 701-719. 
Lardy, N. R. (1983), Agriculture in China's Modern Economic Development, Cambridge: Cambridge University Press.

Li, C. and J. Gibson (2013), 'Rising Regional Inequality in China: Fact or Artifact?', World Development, 47(C): 16-29.

Li, W. and D. T. Yang (2005), 'The Great Leap Forward: Anatomy of a Central Planning Disaster', Journal of Political Economy, 113(4): 840-877.

Lin, J. Y. (1987), 'The Household Responsibility System Reform in China: A Peasant's Institutional Choice', American Journal of Agricultural Economics, 69(20): 410-415.

Lin, J. Y. (1989), 'The Household Responsibility System in China's Rural Reform', in A. Mauder and A. Valdes (eds), Agriculture and Governments in an Interdependent World: Proceedings of the XX International Conference of Agricultural Economists, Aldershot, UK: Dartmouth, pp. 453-462.

Lin, J. Y. (1990), 'Collectivization and China’s Agricultural Crisis in 1959-1961', Journal of Political Economy, 98(6): 12281252.

Lin, J. Y. (1992), 'Rural Reforms and Agricultural Growth in China', American Economic Review, 82(1): 34-51.

Ling, Z. (1997), History is No Longer Hovering, Beijing: People’s Publishing House.

Liu, W. (2013), 'Reexamining the Income Inequality in China: Evidence from Sequential Panel Selection Method', Economic Modelling, 31(C): 37-42.

McMillan, J., J. Whalley and L. Zhu (1989), 'The Impact of China’s Economic Reforms on Agricultural Productivity Growth', Journal of Political Economy, 97(4): 781-807.

Meng, G. (2019), 'The Household Responsibility System, Karl Marx’s Theory of Property and Anthony M. Honoré’s Concept of Ownership', Science \& Society, 83(3): 300-326.

Meng, X., N. Qian and P. Yared (2015), 'The Institutional Causes of China's Great Famine 1959-1961', Review of Economic Studies, 82(4): 1568-1611.

Nolan, P. (1993), 'China’s Post-Mao Political Economy: A Puzzle', Contributions to Political Economy, 12(1): 71-87.

North, D. C. (1990), Institutions, Institutional Change and Economic Performance, Cambridge: Cambridge University Press.

North, D. C. (1999), 'Dealing with a non-Ergodic World: Institutional Economics, Property Rights, and the Global environment', Duke Environmental Law and Policy Forum, 10(1): 1-12.

North, D. C. (2004), 'Institutions and the Performance of Economies over Time', in A. Liebenthal, O. Feinstein, and G. Ingram (eds), Evaluation and Development: The Partnership Dimension, New Brunswick and New Jersey: Transactions Publishers, pp. 1-7.

North, D.C. (2005a), 'The Chinese Menu (for Development)', The Wall Street Journal, 7 April 2005, https://www.wsj.com/ articles/SB111283514152300351.

North, D. C. (2005b), Understanding the Process of Economic Change, Princeton: Princeton University Press.

North, D. C. and R. P. Thomas (1973), The Rise of the Western World: A New Economic History, Cambridge: Cambridge University Press.

North, D. C. and B. R. Weingast (1989), 'Constitutions and Commitment: The Evolution of Institutions Governing Public Choice in Seventeenth-Century England', Journal of Economic History, 49(4): 803-832.

North, D. C., J. J. Wallis and B. R. Weingast (2009), Violence and Social Orders: A Conceptual Framework for Interpreting Recorded Human History, Cambridge: Cambridge University Press.

Oi, J. C. (1999), Rural China Takes off: Institutional Foundations of Economic Reform, Berkeley, CA: University of California Press.

Ostrom, E. (1987), 'Institutional Arrangements for Resolving the Commons Dilemma: Some Contending Approaches', in B. J. McCay and J. M. Acheson (eds), The Question of the Commons: The Culture and Ecology of Communal Resources, Tucson, AZ: University of Arizona Press, pp. 250-265.

Ostrom, E. (1990), Governing the Commons: The Evolution of Institutions for Collective Action, Cambridge: Cambridge University Press.

Ostrom, E. (1993), 'Self-Governance, the Informal Public Economy, and the Tragedy of the Commons', in P. J. Berger (ed.), Institutions of Democracy and Development, San Francisco, CA: ICS Press, pp. 75-125.

Ostrom, E. (2005), Understanding Institutional Diversity, Princeton: Princeton University Press.

Ostrom, E. (2007), 'A Diagnostic Approach for Going Beyond Panaceas', Proceedings of the National Academy of Sciences, 104 (39): 15181-15187.

Ostrom, E. (2009a), 'A General Framework for Analyzing Sustainability of Social-Ecological Systems', Science, 325(5939): $419-422$.

Ostrom, E. (2009b), 'A Polycentric Approach for Coping with Climate Change', World Bank Research Working Paper No. 5095.

Ostrom, E. (2010), 'Beyond Markets and States: Polycentric Governance of Complex Economic Systems', American Economic Review, 100(3): 641-672.

Ostrom, E., R. Gardner and J. Walker (1994), Rules, Games and Common-Pool Resources, Ann Arbor: University of Michigan Press.

Pennington, M. (2013), 'Elinor Ostrom and the Robust Political Economy of Common-Pool Resources', Journal of Institutional Economics, 9(4): 449-468. 
Posner, R. (1975), 'Economic Analysis of Law' in Bruce A. Ackerman (ed.), Economic Foundation of Property Law, Boston, MA: Little, Brown and Co.

Prybyla, J. S. (1990), 'China’s Socialist Economy: A Broken System’ in G. Hicks (ed.), The Broken Mirror: China after Tiananmen, Harlow, Essex: Longman.

Qiao, S. and F. Upham (2015), 'The Evolution of Relational Property Rights: A Case of Chinese Rural Land Reform', Iowa Law Review, 100(6): 2479-2506.

Ravallion, M. (2021), Poverty in China since 1950: A Counterfactual Perspective, NBER Working Paper 28370.

Renda Fazhi Gongzuo Weiyuanhui (RFGW) (1990), Zhonghua Renmin Gongheguo Tudi Guanlifa Shiyi [An Interpretation of the Land Administration Law of the People's Republic of China], Beijing: Falü Chubanshe.Renda Fazhi Gongzuo Weiyuanhui.

Samuelson, P. (1954), 'The Pure Theory of Public Expenditure', Review of Economics and Statistics, 36(4): $387-389$.

Schlager, E. and E. Ostrom (1992), 'Property-Rights Regimes and Natural Resources: A Conceptual Analysis', Land Economics, 68(3): 249-262.

Stinchcombe, A. (2001), When Formality Works: Authority and Abstraction in Law and Organizations, Chicago: University of Chicago Press.

Sun, J. W. (2012), 'China's Rural per Capita Net Income From 1980 to 2000', Central Asian Survey, 22(2-3): 333-337.

Upham, F. (2009), 'From Demsetz to Deng: Speculations on the Implications of Chinese Growth for Law and Development Theory', Journal of International Law and Politics, 41(3): 551-599.

Wang, L. (1988), 'Life after Mao Zedong: A Report on Implementation of and Consequences of Major Chinese Agricultural Policies in Anhui Villages', Kunlun [Lofty Peaks] 57(4-53), Translated: pp. 1-65 in Joint Publication Research Service, CAR-89-079 (July 28, 1989).

Wang, G., X. Yang, Z. Wang, X. Liang and G. Yang (1989), 30 Years in the Village - Memoir of Rural Society and Economic Development of Fengyang 1949-1983 (in Chinese), Vol. 2, Beijing: China Agriculture Press.

Wen, G. J. (1988), The Current Land Tenure and Its Impact on Long Term Performance of the Farming Sector: The Case of Modern China, Ph.D. dissertation, University of Chicago.

Whyte, M. K. (2010), Myth of the Social Volcano: Perceptions of Inequality and Distributive Injustice in Contemporary China, Stanford, CA: Stanford University Press.

Whyte, M. K. (2014), 'Soaring Income Gaps: China in Comparative Perspective', Journal of the American Academy of Arts \& Sciences, 143(2): 39, 52.

Wong, V. (2014), 'Land Policy Reform in China', University of Hong Kong, Centre for Comparative \& Public Law, Occasional Paper, 25(2014): 14-15.

World Bank (2021), The World Bank In China: Overview, Washington, DC: World Bank. Available at https://www.worldbank.org/en/country/china/overview.

Wu, T. (1979), 'A Tonic Worth Every Drop - Investigation of the Xiaogang Production Brigade's "Household Responsibility System" of Liyuan Commune in Fengyang County', in the Editing Office of Agricultural Cooperation System in Contemporary China, ed., The Selecting Writing of History of Classical Agricultural Cooperation in Contemporary China (in Chinese). Beijing: Chinese Agricultural Press.

Wu, X. (2016), Contemporary Chinese Rural Reform, Singapore: Foreign Language Teaching and Research Publishing Co./ Springer Science+Business Media.

Yixin, C. (2010), 'Under the Same Maoist Sky: Accounting for Death Rate Discrepancies in Anhui and Jiangxi', in K. Manning and F. Wemheuer (eds), Eating Bitterness: New Perspectives on China's Great Leap Forward and Famine. Vancouver, BC: UBC Press, pp. 197-225.

Zhang, Q. F. and J. A. Donaldson (2013), 'China's Agrarian Reform and the Privatization of Land: A Contrarian View', Journal of Contemporary China, 22(80): 255-272.

Zhu, L. and Z. Jiang (1993), 'From Brigade to Village Community: The Land Tenure System and Rural Development in China', Cambridge Journal of Economics, 17(4): 441-461.

Cite this article: Deakin S, Meng G (2022). Resolving Douglass C. North's 'puzzle' concerning China's household responsibility system. Journal of Institutional Economics 18, 521-535. https://doi.org/10.1017/S1744137421000746 